${ }^{1}$ N.T. Azhikhanov, ${ }^{2}$ B.T. Zhumagulov, ${ }^{3}$ T.A. Turymbetov, ${ }^{4}$ A.B. Bekbolatov

${ }^{1}$ Doctor of Technical Sciences, Academy of Public Administration under the President of Kazakhstan, Turkestan, Kazakhstan, E-mail: ajihanov1@mail.ru

${ }^{2}$ Doctor of Technical Sciences, Academician of NAS RK, National Engineering Academy of the

Republic of Kazakhstan, Almaty, Kazakhstan, E-mail: zhumagulov_b@mail.ru

${ }^{3}$ Candidate of Technical Sciences, Khoja Akhmet Yassawi International Kazakh-Turkish

University, Turkestan, Kazakhstan, E-mail: tursinbay@mail.ru

${ }^{4} \mathrm{PhD}$ student, Khoja Akhmet Yassawi International Kazakh-Turkish University,

Turkestan, Kazakhstan, E-mail: alimzhan_iktu@mail.ru

\title{
STRESSED-DEFORMED STATE OF TWO DRIFTS IN A TILTLY LAYERED CRACKED ARRAY IN THE CONDITIONS OF ELASTIC DEFORMATIONS OF ROCKS
}

In the study, based on a homogeneous anisotropic mechanical-mathematical model of an inclined, finely layered array with a biperiodic system of slots, the patterns of distribution of elastic stresses and displacements near two drifts of arbitrary profile shape and depth by the finite element method under conditions of plane deformation have been systematically numerically investigated. The calculation was carried out by converting weakened rocks with two excavations in elasticity to an equivalent homogeneous medium. It is difficult to solve the problem of the initial static stress state of two-diagonal workings on a rock weakened by two-period cracks by the analogous method, therefore it was solved by the generalized method of plane deformation using the first and second isoparametric elements by the finite element method. Methods for dividing the area specified by the finite element method into parametric quadrangular elements and numerically determining the stress-strain state of double workings are given.

A computational algorithm has been developed and a software package has been developed for studying the elastic state of adjacent cavities of arbitrary depth and shape. A multivariate numerical calculation and analysis of the influence on the components of stresses and displacements near cavities, geometrical, physical parameters of rocks was carried out.

Key words: drift, isoparametric element, transtropic array, finite element method.

${ }^{1}$ Н.Т. Ажиханов, ${ }^{2}$ Б.Т. Жұмағұлов, ${ }^{3}$ Т.А. Тұрымбетов, ${ }^{4}$ А.Б. Бекболатов

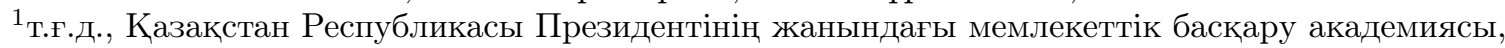

Түркістан қ., Қазақстан, E-mail: ajihanov1@mail.ru

${ }^{2}$ т.ғ.д., ҚР ҰҒА академигі, Қазақстан Республикасының ұлттық инженерлік академиясы,

Алматы қ., Қазақстан, E-mail: zhumagulov_b@mail.ru

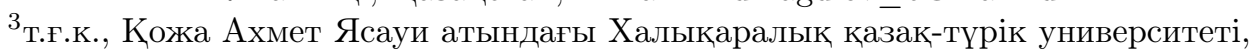

Түркістан қ., Қазақстан, E-mail: tursinbay@mail.ru

${ }^{4} \mathrm{PhD}$ докторант, Қожа Ахмет Ясауи атындағы Халықаралық қазақ-түрік университеті,

Түркістан қ., Қазақстан, E-mail: alimzhan_iktu@mail.ru

Екі штректің серпімді тау жыныстарынының жарықтары массивті салмақты қабаттағы кернеулік-деформациялық жағдайы

Зерттеуде бипериодты саңылаулар жүйесі бар көлбеу, жұқа қабатты массивтік біртекті анизотропты механикалық-математикалық моделін ала отырып, жазықтықтың деформациялану жағдайына шекті элемент әдісін қолдандық және тереңдіктің екі штректің маңайында серпімді кернеулер мен орын ауыстырулардың заңдылықтары жүйелі түрде зерттелді. Тау жыныстарының геометриялық, физикалық параметрлеріне кернеулер мен орын ауыстырулар компоненттеріне әсер етуді сандық есептеу және талдау жүргізілді. 
Қос қазбамен әлсіретілген тау жыныстарын қатаңдығы жағынан эквивалентті біртекті ортаға келтіру есебі арқылы жүзеге асырылды. Салмақты екі периодты жарықтармен әлсіретілген тау жынысында көлденең қимасы әр түрлі қос диагоналдық қазбаның бастапқы статикалық кернеулік күйін аналитикалық әдістермен шешу күрделі болғандықтын есеп шекті элементтер әдісімен бірінші және екінші изопараметрлік элементтерді қолданып, жалпылама жазық деформация шартында шешілді. Шекті элементтер әдісі арқылы берілген облысты төртбұрышты изопараметрлік элементтерге бөлу және қос қазбаның кернеулікдеформациялық күйін сандық анықтау жолдары келтірілді.

Есептеу алгоритмі және еркін тереңдік пен пішіннің іргелес қуыстарының серпімді күйін зерттеуге арналған бағдарламалық кешен жасалынды. Тау жыныстарының геометриялық, физикалық параметрлеріне кернеулер мен орын ауыстырулар компоненттеріне әсер етуді сандық есептеу және талдау жүргізілді.

Түйін сөздер: штрек, изопараметрлік элемент, транстропты массив, шекті элементтік әдіс

${ }^{1}$ Н.Т. Ажиханов, ${ }^{2}$ Б.Т. Жумагулов, ${ }^{3}$ Т.А. Турымбетов, ${ }^{4}$ А.Б. Бекболатов

1 д.т.н., Академия государственного управления при Президенте Республики Казахстан, г. Туркестан, Казахстан, E-mail: ajihanov1@mail.ru

2 д.т.н., академик НАН РК, Национальная инженерная академия Республики Казахстан, г. Алматы, Казахстан, E-mail: zhumagulov_b@mail.ru

${ }^{3}$ к.т.н., Международный казахско-турецкий университет имени Х.А.Ясави, г. Туркестан, Казахстан, E-mail: tursinbay@mail.ru

${ }^{4} \mathrm{PhD}$ докторант, Международный казахско-турецкий университет имени Х.А.Ясави, г. Туркестан, Казахстан, E-mail: alimzhan_iktu@mail.ru

Напряженно-деформированное состояние двух штреков в наклонно слоистом трещиноватым массиве в условиях упругих деформациях пород

В работе на основе однородной анизотропной механико-математической модели наклонного мелкослоистого массива с двоякопериодической системой щелей систематически численно исследовано закономерности распределения упругих напряжений и перемещений вблизи двух штреков произвольной формы профиля и глубины методом конечных элементов в условиях плоской деформации. Расчет был осуществлен с путем превращения ослабленных пород с двумя раскопками по упругости к эквивалентной однородной среде. Решать задачау начального статического напряженного состояния двухдиагональных выработок на породе, ослабленной двухпериодными трещинами по аналогическим методом трудно, по этому была решена обобщенным методом плоской деформации с использованием первого и второго изопараметрических элементов методом конечных элементов. Приведены способы деления площади, заданной методом конечных элементов, на параметрические четырехугольные элементы и численного определения напряженно-деформированного состояния двойных выработок.

Разработан расчетный алгоритм и составлен программный комплекс для изучения упругого состояния сближенных полостей произвольной глубины и формы. Проведен многовариантный численный расчет и анализ влияния на составляющие напряжений и перемещений вблизи полостей, геометроических, физических параметров пород.

Ключевые слова: штрек, изопараметрический элемент, транстропный массив, метод конечных элементов.

\section{Introduction}

In the last century, the works of Soviet and foreign scientists mainly carried out theoretical studies of the VAT of underground cavities in an isotropic massif. Using the symmetry of the biharmonic solution and based on the special properties of the harmonic functions O.Muller [1], K.Stocke [2], the corresponding classes of problems are considered. G.V.Kolosov, N.I.Muskhelishvili [3] successfully solved the theory of functions of a complex variable in solving plane problems in the theory of elasticity of an isotropic body. 
The analytical function proposed by Appel made it possible to consider the state of a single and multiply connected isotropic body with circular holes. An orthotropic medium with a doubly periodic system of round holes was considered by L.A.Filshtinsky [4], and such a body with elliptical holes by A.S.Kosmodamiansky, M.M.Neskorodev [5]. A.S.Kosmodamiansky studied the SSS of an anisotropic elastic body with three and infinite rows of holes and based on these solutions Zh.S.Erzhanov, K.Kaydarov, M.T.Tusupov [6] studied the effects of slot systems on the static stress state of the underground working out. Zh.S.Erzhanov, Sh.M.Aytaliev and Zh.K.Masanov [7] proposed a computational mechanical-mathematical model of elastic deformation of an anisotropic massif with doubly periodic gap systems, and by solving the reduction problem, we obtained elastic constants of a transtropic body equivalent in stiffness to the main an array with gaps, depending on the elastic properties of the latter and the geometry of the gaps. Based on this model, the static initial elastic state of mostly single underground deep-seated cavities was studied using strict and approximate methods.

A significant contribution to the development of the theory of FEM and their application to solving complex problems of statics and dynamics of the mechanics of a deformable body was made by scientists L.Segerlind [8], B.Z.Amusin, A.B. Fadeev [9], Zh.S.Erzhanov, T.D.Karimbaev [10], Sh.M.Aytaliev, Zh.K.Masanov, R.B.Baimakhan, N.M.Makhmetova [11] and others.

\section{Finite elemend method}

The elastic static stress and deformable state of two shallow cavities in a heavy transtropic massif is studied depending on the degree of discontinuity by adhesion of shallow inclined layers at an angle $\phi$. We denote by $H$ the depth of the workings with the distance between their centers $2 L$.

The equation of the generalized Hooke law of an anisotropic array with cavities under generalized plane deformation relative to the Cartesian coordinate system Oxyz (Figure 1) is written as

$$
\{\sigma\}=[\bar{D}]\{\varepsilon\}
$$

where $\{\sigma\}=\left(\sigma_{x}, \sigma_{z}, \sigma_{x z}\right)^{T},\{\varepsilon\}=\left(\varepsilon_{x}, \varepsilon_{z}, \gamma_{x z}\right)^{T},[\bar{D}]=\left[d_{i j}\right],(i, j=1,2, \ldots, 5)$ is strain coefficients [7].

Here $E_{k}^{2}, \nu_{k}^{2}, G_{2}^{2}(k=1,2)$ effective elastic constants of the transtropic massif, equivalent in stiffness to the anisotropic massif with gaps that depend on the elastic constants of the latter $E_{k}, \nu_{k}, G_{2}(k=1,2)$ and slot geometry $a, \omega, i \omega$.

The cross-sectional area ABCD of the drifts during plane deformation is divided using $\mathrm{n}$ nodes into $\mathrm{m}$ isoparametric design elements (Figure 1b). A basic resolving system of 3n-order FEM algebraic equations is compiled with respect to the projections of node displacements and it is solved under the following boundary conditions:

base of the BD settlement area ABCD non-deformable

$$
u=\omega=0
$$


the lateral sides of $\mathrm{AB}$ and $\mathrm{CD}$ under the influence of the weight of the rocks move only in the vertical direction due to the absence of the influence of the cavities

$$
u=0, \quad \omega=\omega(z) .
$$
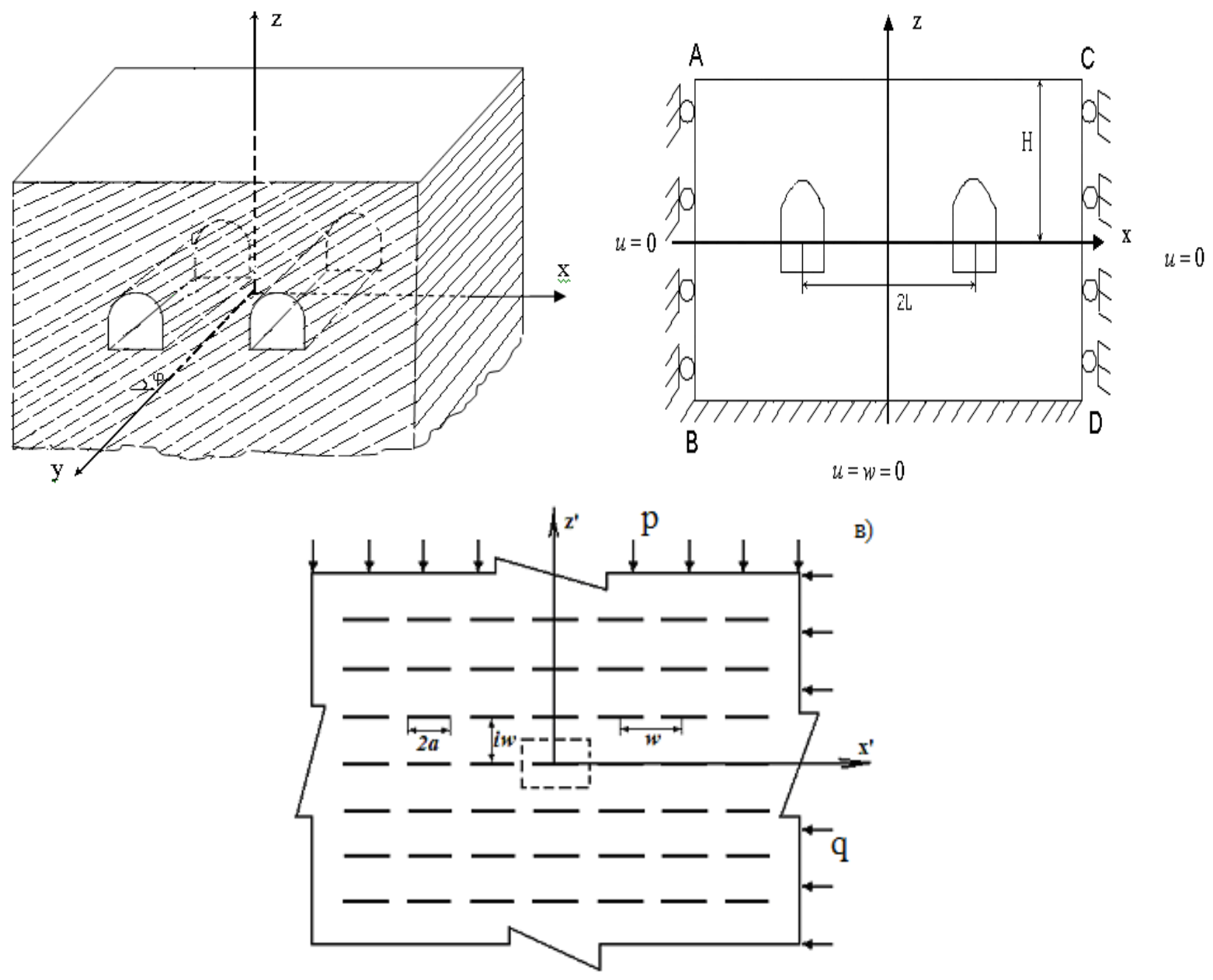

Figure 1: Calculation scheme for studying the stress state of an anisotropic array a) spatial view; b) flat view; c) a plane with a periodic system of slots

The investigated computational domain with cavities is automatically divided into isoparametric elements using the FEM 3D program in the Delphi object-oriented environment. Each node is affected by vertical force by weight.

Solving the basic system of FEM equations with respect to component displacements with boundary conditions 2, 3 by strict methods is difficult; Therefore, it is solved in the paper by the iterative Seidel - Gauss method with the upper relaxation coefficient with a given accuracy [12].

An attractive feature of this method is the following: firstly, the system stiffness matrix is compiled only once $[K]$ and its elements and column matrix elements are used during iteration 
$\{U\}$; secondly, when $k+1$ iterations for unknowns $u_{m+1},(m=1,2, \ldots, 3, n), u_{1}, u_{2}, \ldots, u_{m}$ values needed at $k+1$ iteration, and for $u_{m+2}, \ldots, u_{3 n}$ value at $k$ iteration.

To verify the correct operation of the developed algorithms and software systems, the test problem of the elastic stress state of a circular cavity in an anisotropic array with a horizontal plane of isotropy under conditions of plane deformation and hydrostatic stress distribution in an untouched medium is solved. Due to the symmetry of the problem, a quarter of the region with a cavity is divided into 342 isoparametric elements using 380 nodes. The basic system of 1140-order equations is solved using 1000 iterations. The difference between the displacement values at the characteristic points of the contour obtained by iterative and known rigorous methods is not more than $1-2 \%$.

When calculating the values of the components of displacements and stresses near adjacent drifts of various depths () and the profile shape in a slit-like transtropic massif with incomplete adhesion of layers $(\omega / a=2.5,3,4,6, \infty)$ and inclined plane of isotropy $\left(\varphi=0,30^{\circ}, 45^{\circ}, 60^{\circ}, 90^{\circ}\right)$ the study area was divided into 2064 elements with 2189 nodes.

The calculation results of the study are presented in the form of diagrams; they are analyzed in detail regarding the effect of incoming parameters on the elastic state of underground structures.

Other things being equal, the parameter $\omega / a$ significantly affects displacements near cavities of various shapes; with its decrease, the values of the latter increase (Figures 2,3).

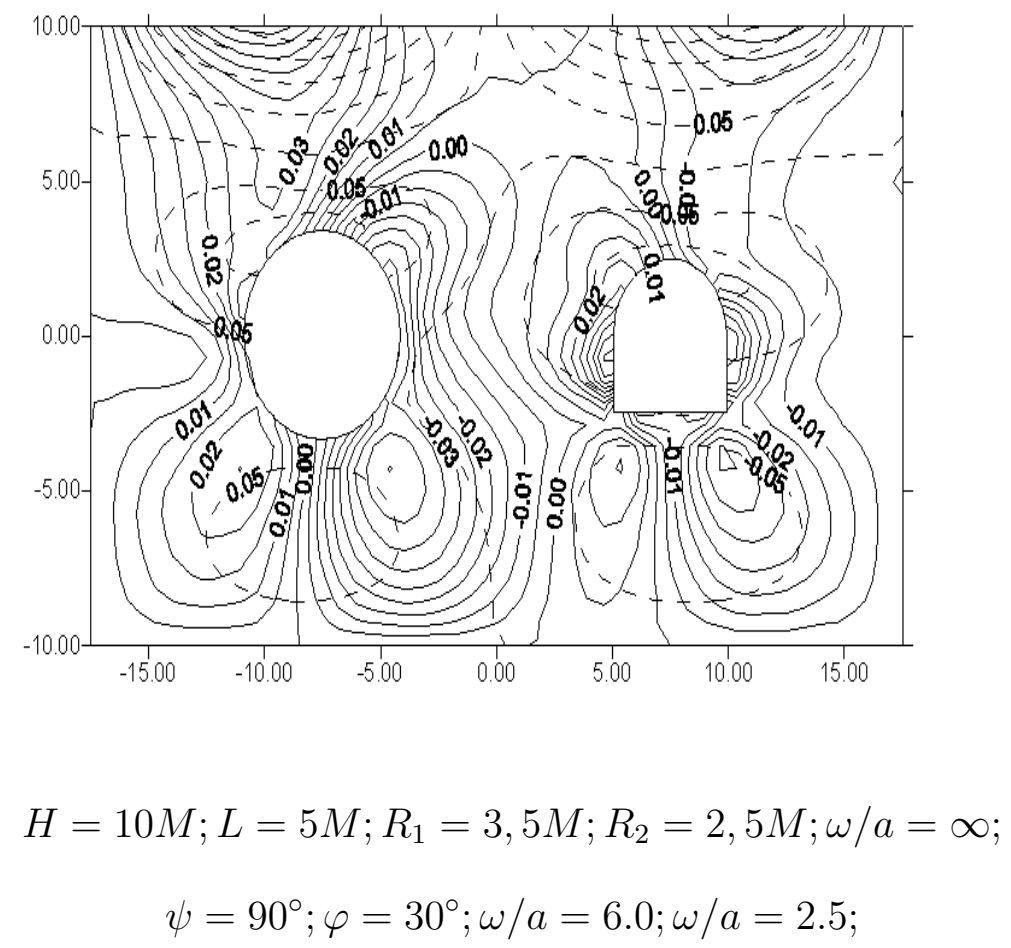

Figure 2: Displacement contours u $(\mathrm{mm})$ around cavities of different profiles. 


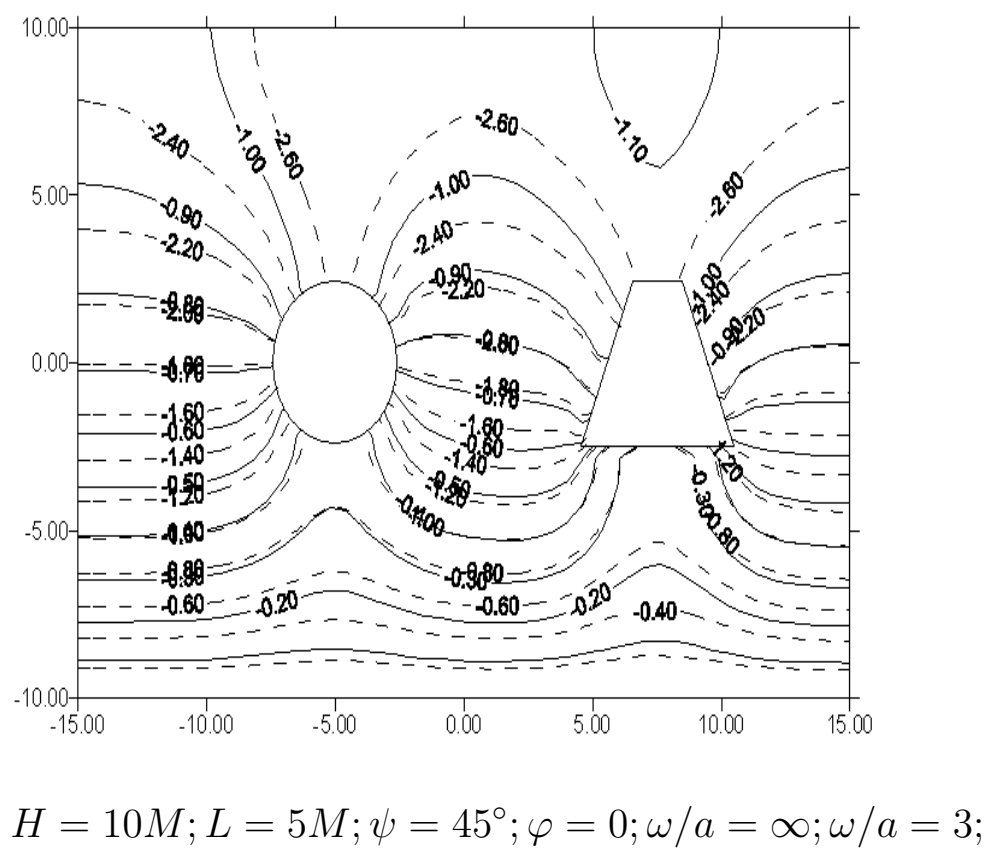

Figure 3: Isolines of vertical displacements $\mathrm{w}(\mathrm{mm})$ around cavities of different profiles.

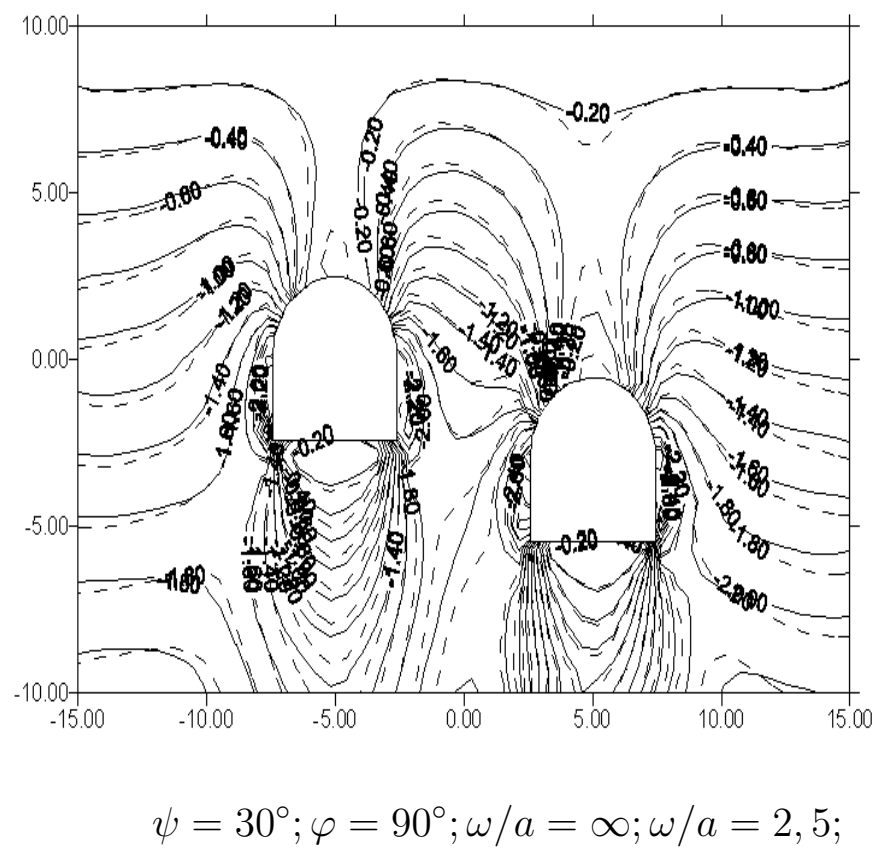

Figure 4: Contours of the vertical movement $\sigma_{z}$ of the plane at different locations. 


\section{Results}

Given 12 points in anisotropic rocks weakened by two elastic periodicities, the value of the change in the tangential stress $\sigma_{\theta} / \gamma H$ in Table 1 was obtained, depending on the proximity of the minerals, the frequency of the stress crack and displacement.

Table 1: Change in displacement depending on the transverse angle $\varphi$ in the horizontal plane

\begin{tabular}{|l|l|l|l|l|l|l|l|l|}
\hline \multirow{2}{*}{ Left fossil } & \multicolumn{2}{l|}{$\varphi=0$} & \multicolumn{2}{l|}{$\varphi=30^{\circ}$} & \multicolumn{2}{l|}{$\varphi=60^{\circ}$} & \multicolumn{2}{l|}{$\varphi=90^{\circ}$} \\
\cline { 2 - 9 } & $u$ & $w$ & $u$ & $w$ & $u$ & $w$ & $u$ & $W$ \\
\hline 1 & $-0,002$ & $-1,03$ & 0,099 & $-1,421$ & 0,267 & $-1,057$ & $-0,002$ & $-0,51$ \\
\hline 2 & $-0,004$ & $-0,992$ & 0,085 & $-1,407$ & 0,318 & $-1,058$ & 0,006 & $-0,483$ \\
\hline 3 & $-0,007$ & $-0,877$ & 0,077 & $-1,278$ & 0,353 & $-0,955$ & 0,009 & $-0,408$ \\
\hline 4 & $-0,008$ & $-0,71$ & 0,069 & $-1,059$ & 0,359 & $-0,777$ & 0,008 & $-0,311$ \\
\hline 5 & $-0,008$ & $-0,525$ & 0,047 & $-0,799$ & 0,321 & $-0,579$ & 0,005 & $-0,209$ \\
\hline 6 & $-0,004$ & $-0,374$ & 0,043 & $-0,592$ & 0,285 & $-0,407$ & 0,002 & $-0,126$ \\
\hline 7 & 0,001 & $-0,317$ & 0,063 & $-0,511$ & 0,263 & $-0,315$ & $-0,001$ & $-0,096$ \\
\hline 8 & 0,005 & $-0,371$ & 0,089 & $-0,564$ & 0,246 & $-0,332$ & $-0,004$ & $-0,125$ \\
\hline 9 & 0,007 & $-0,52$ & 0,102 & $-0,739$ & 0,219 & $-0,462$ & $-0,008$ & $-0,207$ \\
\hline 10 & 0,008 & $-0,703$ & 0,11 & $-0,976$ & 0,197 & $-0,658$ & $-0,01$ & $-0,307$ \\
\hline 11 & 0,004 & $-0,871$ & 0,11 & $-1,2$ & 0,197 & $-0,847$ & $-0,014$ & $-0,404$ \\
\hline 12 & 0,001 & $-0,988$ & 0,113 & $-1,361$ & 0,224 & $-0,983$ & $-0,01$ & $-0,481$ \\
\hline & & & & & & & & \\
\hline \multirow{2}{*}{ Right fossil } & $\varphi=0$ & & $\varphi=30^{\circ}$ & $\varphi=60^{\circ}$ & $\varphi=90^{\circ}$ \\
\cline { 2 - 11 } & $u$ & $w$ & $U$ & $w$ & $u$ & $w$ & $u$ & $W$ \\
\hline 1 & 0,002 & $-1,031$ & 0,378 & $-1,485$ & 0,501 & $-0,823$ & 0,002 & $-0,51$ \\
\hline 2 & 0,004 & $-0,992$ & 0,396 & $-1,507$ & 0,567 & $-0,853$ & $-0,006$ & $-0,483$ \\
\hline 3 & 0,007 & $-0,877$ & 0,372 & $-1,374$ & 0,584 & $-0,8$ & $-0,009$ & $-0,408$ \\
\hline 4 & 0,008 & $-0,71$ & 0,312 & $-1,13$ & 0,547 & $-0,678$ & $-0,008$ & $-0,311$ \\
\hline 5 & 0,008 & $-0,525$ & 0,237 & $-0,842$ & 0,467 & $-0,508$ & $-0,005$ & $-0,209$ \\
\hline 6 & 0,004 & $-0,374$ & 0,153 & $-0,593$ & 0,368 & $-0,36$ & $-0,001$ & $-0,126$ \\
\hline 7 & $-0,001$ & $-0,317$ & 0,082 & $-0,47$ & 0,273 & $-0,283$ & 0,001 & $-0,097$ \\
\hline 8 & $-0,005$ & $-0,371$ & 0,041 & $-0,5$ & 0,204 & $-0,29$ & 0,004 & $-0,125$ \\
\hline 9 & $-0,007$ & $-0,52$ & 0,045 & $-0,65$ & 0,174 & $-0,363$ & 0,008 & $-0,207$ \\
\hline 10 & $-0,008$ & $-0,703$ & 0,099 & $-0,868$ & 0,2 & $-0,475$ & 0,01 & $-0,308$ \\
\hline 11 & $-0,004$ & $-0,871$ & 0,185 & $-1,11$ & 0,274 & $-0,611$ & 0,014 & $-0,404$ \\
\hline 12 & $-0,001$ & $-0,988$ & 0,297 & $-1,33$ & 0,382 & $-0,731$ & 0,01 & $-0,481$ \\
\hline
\end{tabular}

\section{Conclusion}

When the cavities are at different levels, the stress distribution is very difficult; they change with growth $w / a$. At an angle of inclination of the plane of isotropy $\varphi=0,90^{\circ}$ (and slit planes) 
of a slit-like massif with cavities, all other things being equal, both stress and displacement are distributed around them symmetrically with respect to the vertical axis $O z$ and grow with the depth of the structures stresses decrease, displacements increase with decrease $w / a$; when $\varphi \neq 0,90^{\circ}$ both stresses and displacements are symmetrical about the vertical axis $O z$. With a length of $5 \mathrm{D}$ or more, where $\mathrm{D}$ is the largest diameter of the cavities, the mutual influence of the structures is negligible.

\section{References}

[1] Muller O., "Untersuchungen an Karbongesteinen zur Klarung von Gebirgsdruckfragen", Gluckauf 47(1930): 1601-12.

[2] Stocke K., "Fur das Gebingsdruckproblem wichtige Begriffe aus der technischen Mechanik", Zeitschrift fur des BergHutten und Salinenwesen Bd. 84, H. 11(1937): 465-67.

[3] Muskhelishvili N.I., "Some basic tasks of the mathematical theory of elasticity", Moscow: Nauka (1966): 707.

[4] Filshtinsky L.A., "Stresses in Regular Double-Periodic Lattices", Journal of Engineering. Solid Mechanics (1967): 112.

[5] Cosmodamian A.S.,Neskorodev M.M., "The double-periodic problem for an anisotropic medium weakened by elliptical holes", Dopovidi AN URSR ser. A (1970): 148.

[6] Yerzhanov Zh.S., Kaydarov K.K. and Tusupov M.T., "A mountain massif with incomplete adhesion of layers" , Mechanical processes in a mountain massif Alma-Ata, Nauka (1969): 115.

[7] Erzhanov Zh.S., Aitaliev Sh.M. and Masanov J.K., "Stability of horizontal workings in an inclined-layered massif" , AlmaAta, Nauka (1971): 160.

[8] Segerlind L., "Application of the finite element method", M.: Mir (1979): 392.

[9] Amusin B.Z. and Fadeev A.V., "The finite element method in solving problems of mining mechanics", M.: Nedra (1975): 142 .

[10] Yerzhanov Zh.S. and Karimbaev T.D., "The finite element method in problems of rock mechanics", Alma-Ata: Nauka (1975): 238.

[11] Aitaliev Sh.M., Masanov Zh.K., Baymakhanov I.B. and Makhmetova N.M., "Seismic stress state of paired tunnels", Computational methods for solving the problems of mechanics of a deformable solid Karaganda (1987): 3-15.

[12] Jean-Michel H., "Hydrodynamics of Free Surface Flows", Modeling with the Finite Element Method 1st Edition The USA (2007): 360 .

[13] Mahmetova N.M., Solonenko V.G. and Bekzhanova S.T., "The calculation of free oscillations of an anisotropic threedimensional array of underground structures" , Bulletin of National Academy of Sciences of the Republic of Kazakhstan (2017): 24-28.

[14] Khoei A.E., and Haghighat, "Extended finite element modeling of deformable porous media with arbitrary interfaces", Applied Mathematical Modeling (2011): 5426-5441.

[15] Iktisanov V., "Hydrodynamic research methods and modeling of multilateral horizontal wells", Publishing house (2007): 56.

[16] Khodabakhshi G., Spataru C., "Development of a predictive mathematical model for fluid-porous media interaction problems", Supplement Proceedings of ICMI (2006): 123-138.

[17] Vu M., Sulem J., Subrin D., Monin M., "Semi-Analytical Solution for Stresses Mathematical Model of Fluid Filtration to Horizontal Well 211 and Displacements in a Tunnel Excavated in Transversely Isotropic Formation with Non-Linear Behavior", Rock Mechanics (2013): 213-229.

[18] Wang H.F., "Princeton University Press: Theory of linear poroelasticity with applications to geo mechanics and hydrogeology", New Jersey (2000), 276.

[19] Ali E., Guang W., Zhiming Zh., Weixue J., "Assessments of Strength Anisotropy and Deformation Behavior of Banded Amphibolite Rocks", Geotechnical Geological Engineering (2014): 429-438. 
[20] Wittke W., Ernst and Sohn GmbH., "Rock Mechanics Based on an Anisotropic Jointed Rock Model" , New-York (2014): 875 .

[21] Alabi O.O., Ajah D.T. and Abidoye L.K., "Mathematical Modeling of Hydraulic Conductivity in Homogeneous Porous Media: Influence of Porosity and Implications in Subsurface Transport of Contaminants", Electronic Journal of Geotechnical Engineering (2016): 89-102. 